\title{
Oxygen Radical Generation in Chilled Leaves of Cucumber (Cucumis sativus L.) Cultivars with Different Tolerances to Chilling Temperatures
}

\author{
Wenyun Shen, Kazuyoshi Nada and Shoji Tachibana \\ Faculty of Bioresources, Mie University, Tsu, Mie 514-8507
}

\begin{abstract}
Summary
The possible involvement of oxygen radical generation in chilled leaves in the different chilling tolerances of cucumber (Cucumis sativus L.) cultivars was investigated. Plants with their first expanded leaves were exposed to $3^{\circ} \mathrm{C}$ or $15^{\circ} \mathrm{C}$ in the dark for $24 \mathrm{hr}$; they were warmed for another $24 \mathrm{hr}$ at $28 / 22{ }^{\circ} \mathrm{C}$ (day/night) with a $12-\mathrm{hr}$ photoperiod. Chilled leaves subsequently developed chilling injury symptoms (marginal and inner necrosis) and accumulated malondialdehyde (MDA). Both chilling injury and rate of MDA accumulation were largest in 'Suyo', intermediate in 'Sharp I', and smallest in 'Jinchun No.3'.

In leaves of chilling-sensitive 'Suyo'; NADPH - dependent superoxide and hydrogen peroxidegenerating activities increased markedly during chilling. Hydroxyl radical-generating activities as indicated by methane sulfonic acid formation increased rapidly upon warming, with a concomitant decrease in activities of superoxide and hydrogen peroxide generation. The NADPHdependent superoxide-generating activity increased again during the later warming period. In contrast, chilled leaves of chilling-tolerant 'Jinchun No.3' showed only a slight increase in the oxygen radical generation activities during both chilling and warming periods. In chilled leaves of 'Sharp I', activities of hydrogen peroxide and hydroxyl radical generation increased during the early warming period, whereas those of NADPH-dependent superoxide generation occurred later. The NADPH oxidase activity in chilled leaves changed with time similarly to the activity of NADPH - dependent superoxide generation in all cultivars examined.

The results indicate that chilling injury of cucumber leaves is caused by the increased oxygen radical generation under chilling and subsequent warming conditions. This increase in oxygen radical generation may be triggered primarily by the increased NADPH oxidase activity, the rate of which determines the degree of chilling tolerance in cucumber cultivars.
\end{abstract}

Key Words: chilling tolerance, cucumber, lipid peroxidation, NADPH oxidase, oxygen radical.

\section{Introduction}

Tolerance to chilling temperatures is one of the most important agricultural traits of crop plants, particularly with temperate zone fruit vegetables including cucumber. Recent advances in plant molecular biology and biotechnology have made it possible to improve the chilling tolerance of crop plants by genetic manipulation (Murata et al., 1992; Kodama et al., 1994). To establish further such modern breeding techniques, it is necessary to clarify the physiological and molecular mechanisms for the genetic variations in chilling tolerances of crop plants.

The chilling tolerance of plants is related mainly to the physical properties of membrane lipids (Lyons, 1973; Lynch, 1990). According to Raison et al. (1979), membrane lipids of chilling-sensitive species undergo a phase transition at chilling temperatures from liquid-

Received; August 28, 1998. Accepted; December 2, 1998 crystalline to gel state that leads to dysfunction of membranes and eventually death of cells. The critical temperature for the phase transition of membrane lipids is correlated with the degree of fatty acid unsaturation of the lipids (Markhart et al., 1980; Kodama et al., 1994).

Evidently, lipid peroxidation, caused by chill-induced increases in oxygen radical generation, is the primary cause of chilling injury of plants under both light and dark conditions (Gupta et al., 1993; Prasad et al., 1994; Jakob and Heber, 1996). Lukatkin et al. (1995) found that lipid peroxidation in cucumber leaves increased three-fold when chilled at $3{ }^{\circ} \mathrm{C}$ in the dark for $24 \mathrm{hr}$. However, little is known about whether oxygen radical generation and its detoxifying activity in chilled leaves are implicated in the genetic variations in chilling tolerance among cucumber cultivars. Thus, the objective of the present study was to compare cucumber cultivars with different chilling tolerance with respect to oxygen radical generation in leaves during and after chilling. 


\section{Materials and Methods}

\section{Plant materials}

Two Japanese cultivars of cucumber (Cucumis sativus L.) 'Suyo' and 'Sharp I' and a Chinese cultivar 'Jinchun No.3' were used in this study. The seeds were germinated in vermiculite in the greenhouse and the plants at the cotyledonary stage were transplanted to clay pots $(10 \mathrm{~cm}$ in diameter) filled with commercial fertilized soil. They were grown in a growth chamber $\left(28 / 22^{\circ} \mathrm{C}\right.$ light/dark air temperatures, $60 \sim 70 \%$ relative air humidity, 12 - hr photoperiods under $180 \mu \mathrm{mol} \mathrm{m}^{-2} \mathrm{~s}^{-1}$ PPFD at the foliar canopy level), until the first leaves had fully expanded.

\section{Chilling treatment}

One lot of plants, raised as above, was exposed to a chilling temperature of $3 \pm 0.3{ }^{\circ} \mathrm{C}$ for $24 \mathrm{hr}$ in the dark incubator maintained at nearly $100 \% \mathrm{RH}$. Another lot of plants, which was exposed to $15 \pm 1{ }^{\circ} \mathrm{C}$ for $24 \mathrm{hr}$ in the dark incubator controlled at $60 \sim 70 \% \mathrm{RH}$, served as the control. At the end of the treatments, pots were dipped in tap water (ca. $20^{\circ} \mathrm{C}$ ) for $10 \mathrm{~min}$ in the dark lowtemperature room to raise soil temperatures. Then, the plants were returned to the initial growth chamber where the daytime regime was initiated (rewarming).

\section{Measurement of the incidence of chilling injury}

Three methods were employed for measuring the incidence of chilling injury. The first method was based on the severity of visible injury in the first leaf. Injured leaf areas were determined at the end of the $24 \mathrm{hr}$ warming period, and expressed in percent of total leaf areas. The second one was based on the chill-induced growth inhibition of shoots. For this measurement, plants from both treatments were transferred to the greenhouse and their shoot dry weights were determined after 7 days. The third one determined the levels of malondialdehyde (MDA) in the first leaves as an indication of lipid peroxidation (Lukatkin et al., 1995). The first leaves were collected from chilled and control plants at $6 \mathrm{hr}$ intervals from the beginning of treatments to the end of the $24 \mathrm{hr}$ rewarming period. MDA was determined by the modified method of Heath and Packer (1968). The results are means of at least 3 analyses.

\section{Assays of oxygen radicals and NADPH oxidase}

Leaf samples were prepared similarly to MDA assays and stored at $-30^{\circ} \mathrm{C}$ until analysis. The NADPH-dependent superoxide generating-activity was assayed at 30 ${ }^{\circ} \mathrm{C}$ based on the rate of superoxide dismutase - inhibitory ferricytochrome $\mathrm{c}$ reduction of the $5,000 \mathrm{x}$ g centrifugal supernatant of leaf extracts in the presence of NADPH (Cakmak and Marschner, 1988). Hydrogen peroxide was extracted in 5\% trichloroacetic acid and quantified by the titanic complexes formed by the reaction of leaf extracts with $16 \%$ titanic tetrachloride in concentrated $\mathrm{HCl}$ (Brennan and Frenkel, 1977). Hydroxyl radicals were assayed according to Jakob and Heber (1996) by adding dimethylsulfoxide to the leaf extract at room temperature for $30 \mathrm{~min}$ and estimating methane sulfonic acid (MSA), their reaction product. The activity of NADPH oxidase was determined under similar conditions to the assay of NADPH-dependent superoxide generating-activities, except that ferricytochrome $\mathrm{c}$ was omitted in the reaction mixture (Cakmak and Marschner, 1988). Proteins in the leaf extracts were determined by the method of Bradford (1976). The results are means of at least 3 analyses.

\section{Results}

\section{Differences in the chilling tolerance among cucumber cultivars}

Leaves of all three cultivars wilted soon after the chilled plants were transferred back to the warm growth chamber. They recovered turgor within $1 \mathrm{hr}$, but leaf margins did not recover from wilting and eventually became desiccated and necrotic. Yellow-colored necrotic spots developed on the inner part of leaves after about $6 \mathrm{hr}$, which grew progressively larger with time. At the end of the $24 \mathrm{hr}$, the percent leaf area of both marginal and inner necrotic zones was largest in 'Suyo', intermediate in 'Sharp I' and smallest in 'Jinchun No.3' (Table 1). Shoot growth of chilled plants was inhibited compared to control plants, the inhibition being largest in 'Suyo', intermediate in 'Sharp I' and smallest in 'Jinchun No.3' (Table 2).

The MDA content in chilled leaves was equal to the control during chilling, but began to increase upon rewarming (Fig. 1). This increase was largest in 'Suyo' followed by 'Sharp I' and smallest in 'Jinchun No.3'. The MDA levels in chilled leaves at the end of the $24 \mathrm{hr}$ rewarming period were closely correlated to the severity of chilling injury in the first leaves and the rate of shoot growth inhibition (Fig. 2).

Table 1. The incidence of chilling injury in the first leaf of cucumber cultivars. Injured leaf area as percent of total area was measured on plants chilled at $3{ }^{\circ} \mathrm{C}$ for $24 \mathrm{hr}$ in the dark and then transferred to a growth chamber $\left(28 / 22^{\circ} \mathrm{C}\right.$ day/night under 12 - hr photoperiod) for $24 \mathrm{hr}$.

\begin{tabular}{lccc}
\hline \multirow{2}{*}{ Cultivar } & \multicolumn{3}{c}{ Percentage of injured leaf area } \\
\cline { 2 - 4 } & $\begin{array}{c}\text { Marginal } \\
\text { necrosis }\end{array}$ & $\begin{array}{c}\text { Inner } \\
\text { necrosis }\end{array}$ & Total \\
\hline Jinchun No.3 & $5.61 \mathrm{a}^{2}$ & $0.36 \mathrm{a}$ & $5.97 \mathrm{a}$ \\
Sharp I & $10.18 \mathrm{~b}$ & $2.91 \mathrm{~b}$ & $13.09 \mathrm{~b}$ \\
Suyo & $13.53 \mathrm{~b}$ & $5.56 \mathrm{c}$ & $19.09 \mathrm{c}$ \\
\hline
\end{tabular}

\footnotetext{
${ }^{2}$ Means within a column followed by different letters are significantly different at $p=0.05$.
} 
Table 2. Effect of chilling treatment on the subsequent shoot growth of cucumber culitivars. Plants were exposed to $3{ }^{\circ} \mathrm{C}$ or $15^{\circ} \mathrm{C}$ for $24 \mathrm{hr}$ in the dark and then transferred to a greenhouse for 7 days.

\begin{tabular}{|c|c|c|c|}
\hline \multirow{2}{*}{ Cultivar } & \multicolumn{2}{|c|}{ Shoot dry wt (g plant $\left.{ }^{-1}\right)$} & \multirow{2}{*}{$\begin{array}{l}\text { Inhibition by chilling } \\
(\%)^{z}\end{array}$} \\
\hline & Chilled $\left(3^{\circ} \mathrm{C}\right)$ & Control $\left(15^{\circ} \mathrm{C}\right)$ & \\
\hline Jinchun No.3 & $0.76 \mathrm{a}^{\mathrm{y}}$ & $0.94 \mathrm{a}$ & $19.1 \mathrm{c}$ \\
\hline Sharp I & $0.65 \mathrm{a}$ & $0.93 a$ & $30.1 b$ \\
\hline Suyo & $0.59 b$ & $0.93 a$ & $36.6 \mathrm{a}$ \\
\hline
\end{tabular}

${ }^{z}$ Inhibition was calculated by the following equation.

Inhibition (\%)=(1 - shoot dry wt of chilled plants/shoot dry wt of control plants) $x 100$

${ }^{y}$ Means within a column followed by different letters are significantly different at $p=0.05$.
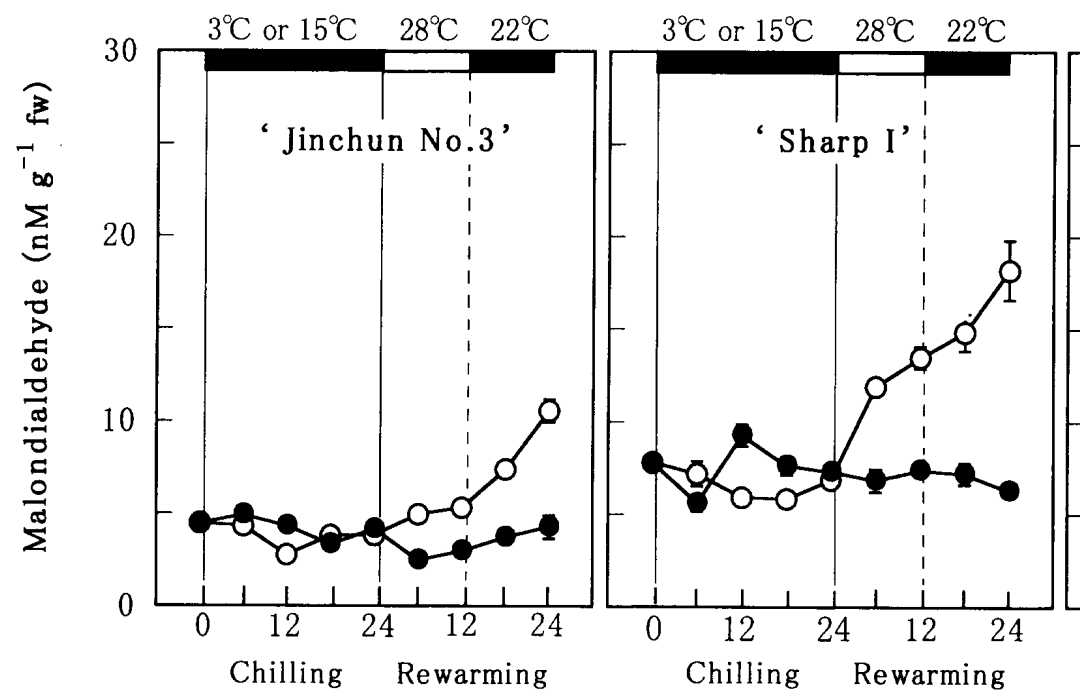

$3^{\circ} \mathrm{C}$ or $15^{\circ} \mathrm{C} \quad 28^{\circ} \mathrm{C} \quad 22^{\circ} \mathrm{C}$

Time of treatment ( $h r)$

Fig. 1. Time-course changes in malondialdehyde formation in cucumber leaves during chilling and rewarming periods. Temperature and light conditions are shown in the upper part of the panels. Error bars indicate SE values. $\bigcirc: 3{ }^{\circ} \mathrm{C}, 0: 15^{\circ} \mathrm{C}$.

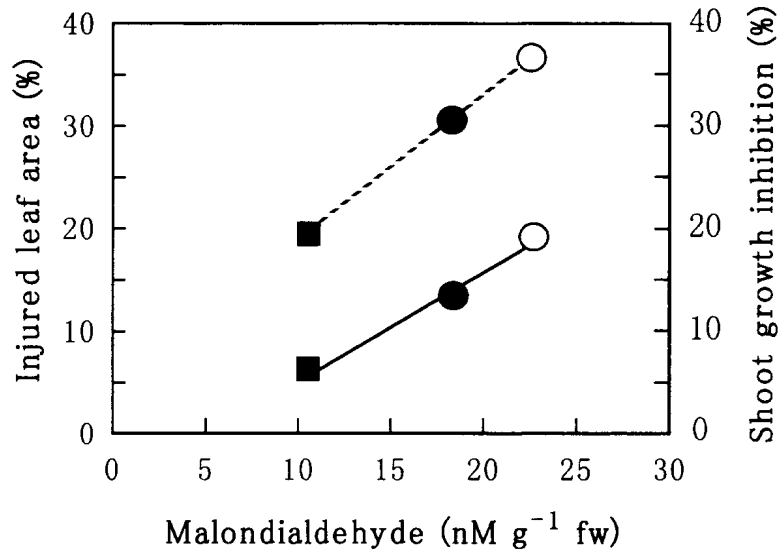

Fig. 2. Relationships between the incidence of chilling injury and the malondialdehyde content in chilled cucumber leaves after rewarming for $24 \mathrm{hr}$. Chilling injury was evaluated by the necrotic leaf area as percent of the total area of the first leaf at the end of the $24 \mathrm{hr}$ rewarming period (-), and the rate of shoot growth inhibition in the greenhouse for 7 days following chilling (---).

'Jinchun No.3', : 'Sharp I' and $\bigcirc$ : 'Suyo'.

\section{Changes in the leaf activities of oxygen radical gener- ation and NADPH oxidase during chilling and rewarming}

The NADPH-dependent superoxide-generating activity in chilled leaves of 'Jinchun No.3' was not significantly different from that in control leaves during chilling and rewarming periods (Fig. 3). Whereas, in 'Suyo' leaves, it increased markedly during 6 to $18 \mathrm{hr}$ of chilling. Following a rapid decline at the end of the chilling period, the rate again increased after $12 \mathrm{hr}$ in the rewarming period. The activity in 'Sharp I' leaves increased during chilling, but to a much lesser extent than in 'Suyo' leaves. The activity increased again after $12 \mathrm{hr}$ rewarming at a similar rate to Suyo' leaves.

The hydrogen peroxide level increased only slightly in 'Jinchun No.3' and 'Sharp I' leaves during the chilling treatment (Fig. 4). In 'Sharp I' leaves, it increased temporarily but significantly immediately after the chilled plants were rewarmed. In chilled leaves of 'Suyo', hydrogen peroxide generation nearly doubled by 

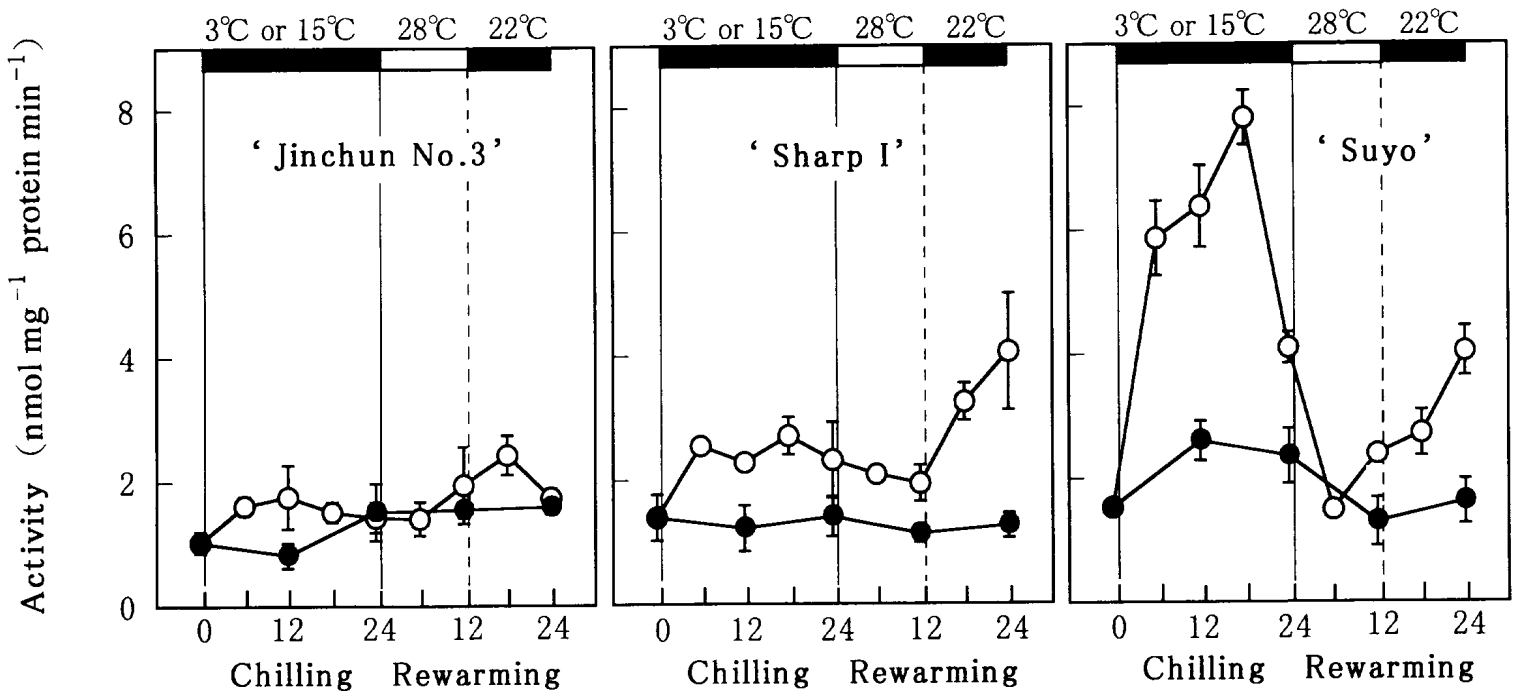

Time of treatment $(\mathrm{hr})$

Fig. 3. Time-course changes in NADPH-dependent superoxide-generating activities in cucumber leaves during chilling and rewarming periods. Temperature and light conditions are shown in the upper part of the panels. Error bars indicate SE values. $\bigcirc: 3^{\circ} \mathrm{C}$, $: 15^{\circ} \mathrm{C}$.
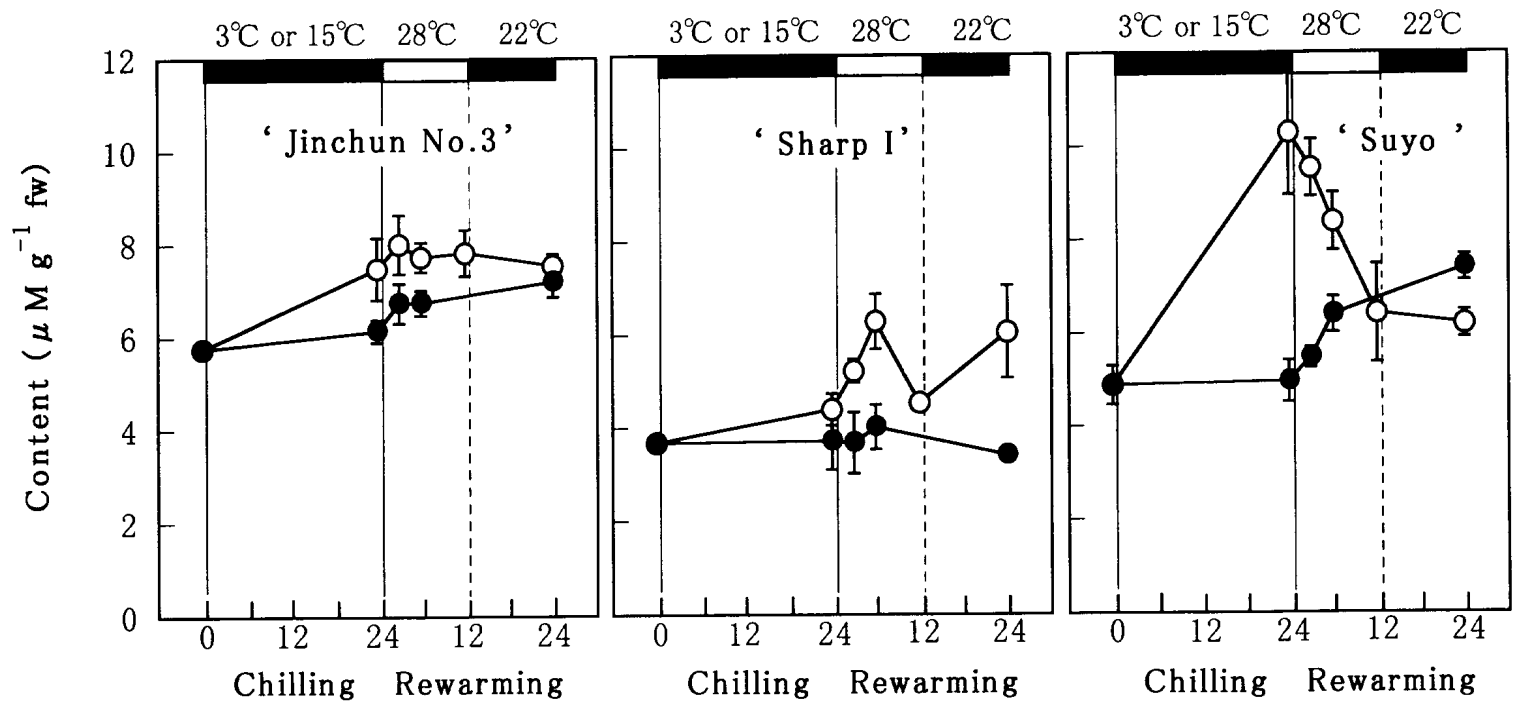

Time of treatment (hr)

Fig. 4. Time-course changes in hydrogen peroxide content in cucumber leaves during chilling and rewarming periods. Temperature and light conditions are shown in the upper part of the panels. Error bars indicate SE values. $\bigcirc: 3{ }^{\circ} \mathrm{C}, 0: 15^{\circ} \mathrm{C}$.

the end of the chilling treatment. It declined rapidly after the plants were transferred to the warm chamber. Control leaves of 'Suyo' also showed a significant increase in hydrogen peroxide during the early rewarming period.

The hydroxyl radical generating-activity in chilled leaves, as indicated by MSA formation, was not different from that in control leaves during chilling in all three cultivars examined (Fig. 5). However, chilled leaves showed increased activities over control leaves during rewarming. This increase was much greater in 'Suyo' than in 'Sharp I' and in 'Jinchun No.3'. The activity peaked at the end of light rewarming period in 'Suyo', whereas in 'Sharp I', the peak occurred in the middle of the subsequent dark period.

The NADPH oxidase activity in chilled leaves changed with time similarly to the NADPH-dependent superoxide-generating activity in all three cultivars examined (Fig. 6). The NADPH oxidase activity in chilled 'Suyo' leaves increased significantly not only during chilling but also during the rewarming period. The activity in chilled 'Sharp I' leaves gradually increased toward the end of the rewarming period. The enzyme activity in chilled 'Jinchun No.3' leaves was also higher than that in control leaves, particularly during rewarming, but the difference between the treat- 

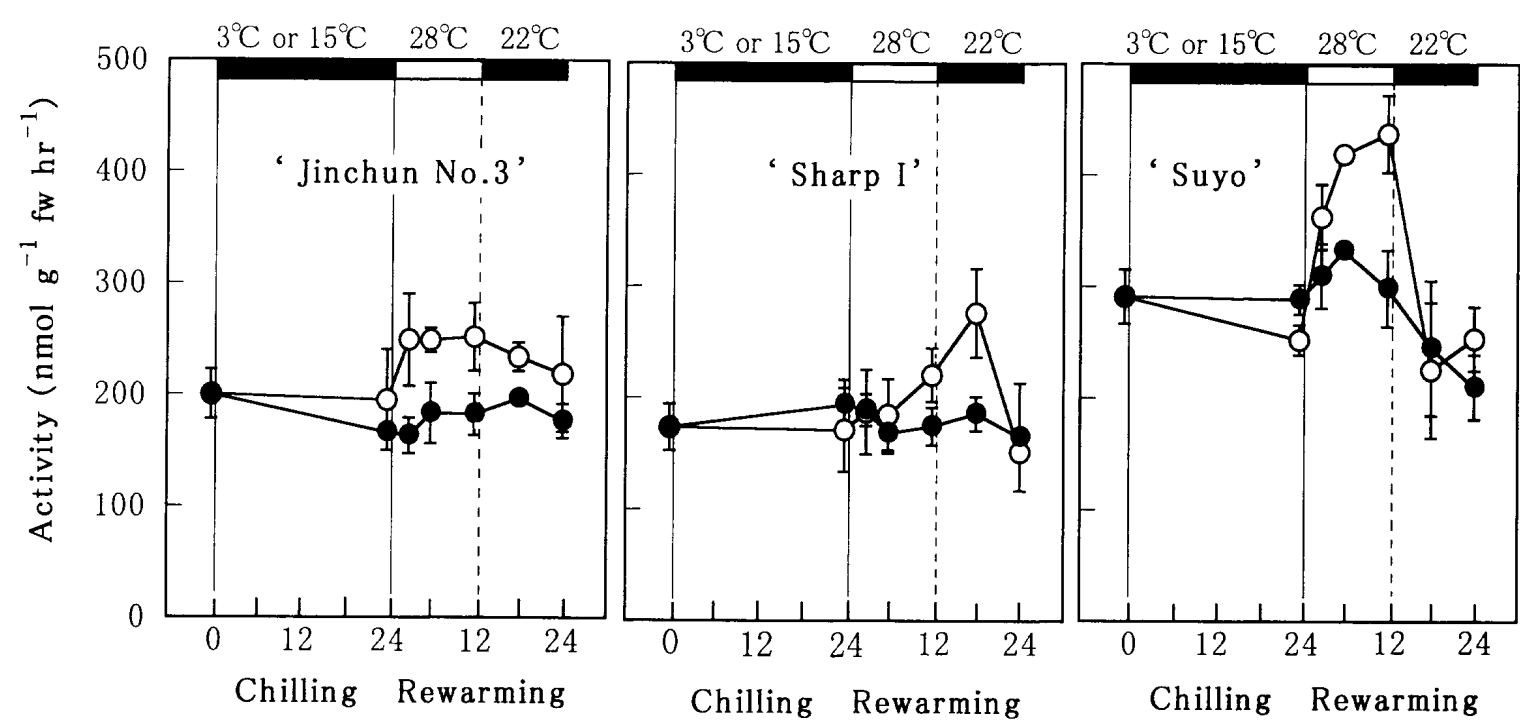

Time of treatment (hr)

Fig. 5. Time-course changes in hydroxyl radical-generating activity in cucumber leaves during chilling and rewarming periods. Hydroxyl radical generation was estimated by the formation of methane sulfonic acid (MSA) (for details see text). Temperature and light conditions are shown in the upper part of the panels. Error bars indicate SE values. $\bigcirc: 3{ }^{\circ} \mathrm{C}, 0: 15^{\circ} \mathrm{C}$.
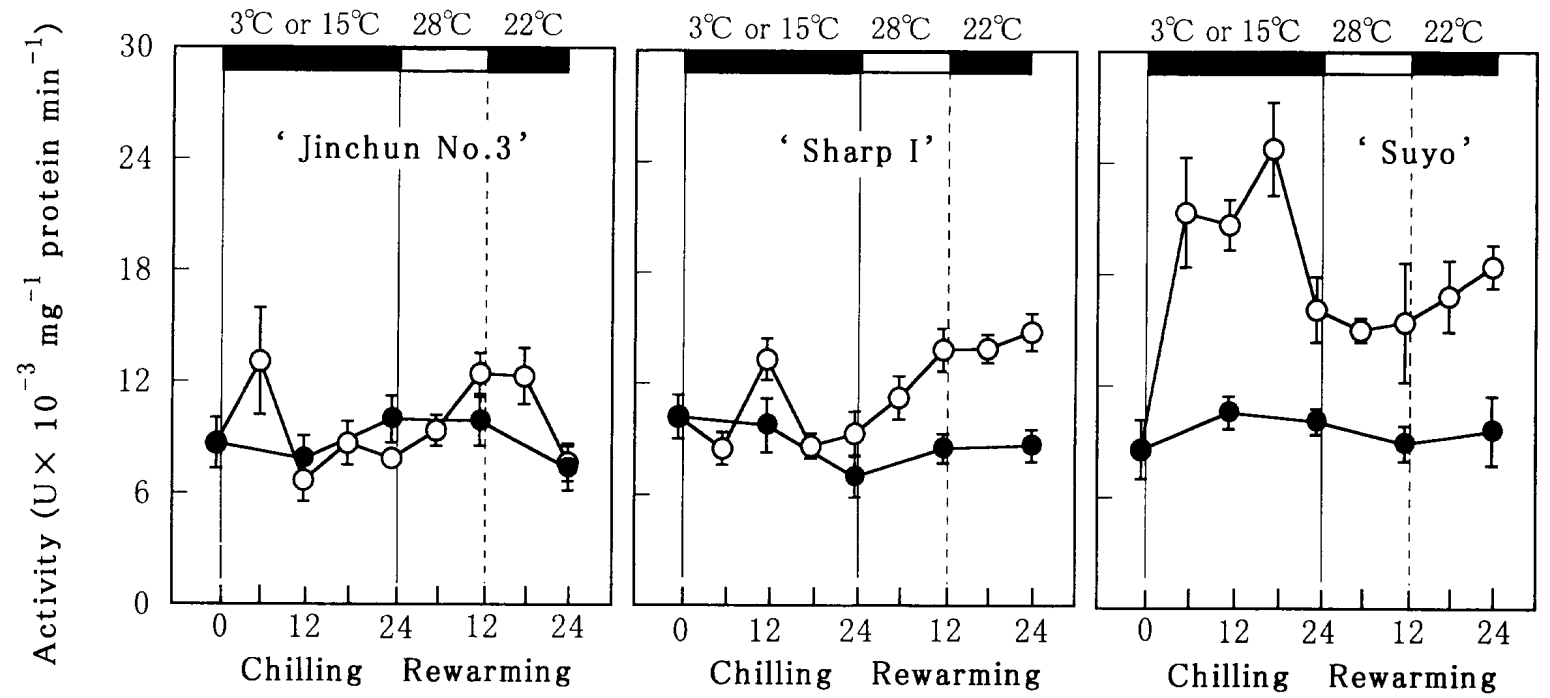

Time of treatment (hr)

Fig. 6. Time-course changes in NADPH oxidase activity in cucumber leaves during chilling and rewarming periods. One unit (U) of activity is equivalent to $1.0 \mu \mathrm{mol}$ NADPH oxidized per min. Temperature and light conditions are shown in the upper part of the panels. Error bars indicate SE values. $\mathrm{O}: 3^{\circ} \mathrm{C}, 0: 15^{\circ} \mathrm{C}$.

ments was much smaller, compared to 'Suyo' and 'Sharp I'.

\section{Discussion}

\section{Physiological causes of chilling injury in cucumber leaves}

The development of necrotic spots in the inner part of chilled leaves paralleled with MDA accumulation with respect to timing and extent. MDA is formed during peroxidation of polyunsaturated fatty acids (Heath and
Packer, 1968), a large proportion of which makes up the membrane lipids (Schwertner and Biale, 1973). Thus, the primary cause of necrotic spot development in chilled cucumber leaves is probably the peroxidation of leaf membrane lipids. Hariyardi and Parkin (1993) came to the same conclusion based on the observation that lipid fluorescent pigments accumulated in leaves of chilled cucumber seedlings during rewarming.

The necrotic margin of chilled and wilted leaves contained MDA about 2.5 times higher than the margin of leaves desiccated artificially by leaving the unchilled, 
excised shoots in the light (data not shown). Thus, marginal necrosis of chilled leaves was also caused probably by the loss of membrane integrity due to chillinduced oxidative stress, resulting in an increased permeability of cytoplasmic membranes (Pauls and Thompson, 1984).

The inhibition of regrowth of chilled plants under normal conditions was greater in the cultivar that accumulated more MDA in the first leaves after $24 \mathrm{hr}$ of rewarming. This result suggests that in chilling-sensitive Suyo', immature leaves and even the shoot apex suffered greatly from membrane lipid peroxidation by chilling.

\section{Relationships between oxygen radical generation in chilled leaves and the chilling tolerance of cucumber cultivars}

Lipid peroxidation is caused mainly by enhanced generation of oxygen radicals such as superoxide, hydrogen peroxide and particularly hydroxyl radicals (Asada et al., 1977). In this study, MDA in chilled leaves increased after the plants were warmed, accompanied by an increase in hydroxyl radical-generating activity. Therefore, hydroxyl radicals are probably the direct cause of increased lipid peroxidation in chilled cucumber leaves.

Once membrane lipid peroxidation has begun, lipid peroxyl radical intermediates can propagate a chain reaction among fatty acids in the membrane, leading to the formation of highly reactive lipid radicals (Crofts et al., 1990). Probably, the occurrence of this chain reaction contributed to the continued increase of MDA in chilled leaves until the end of the rewarming period, even though the hydroxyl radical-generating activity had declined to the control level.

Superoxide anions are dismuted to hydrogen peroxide by superoxide dismutase, and the resultant hydrogen peroxide reacts with superoxide anions to form hydroxyl radicals by the Habar-Weiss reaction or converts directly to hydroxyl radicals in the presence of $\mathrm{Fe}^{2+}$ by a Fenton-type reaction (Salin, 1988). Therefore, superoxide anions and hydrogen peroxide are the precursors of highly reactive hydroxyl radicals.

However, the hydroxyl radical generating - activity in 'Suyo' leaves did not increase during chilling in the dark, in spite of the marked increase in NADPHdependent superoxide - and hydrogen peroxide-generating activities. Furthermore, hydroxyl radical-generating activities in chilled 'Suyo' leaves declined rapidly after $18 \mathrm{hr}$ of rewarming when the plants were in the dark. Jacob and Heber (1996) found that hydroxyl radical generation in a suspension of thylakoids was stimulated by illumination. Reduced ferredoxin in chloroplasts reacts with hydrogen peroxide to form hydroxyl radicals in a Fenton-type reaction (Hosein and Palmer, 1983). Thus, it is possible that the chloroplast is a main site of the increased hydroxyl radicals in chilled leaves of 'Suyo'. However, in chilled 'Sharp I' leaves the hydroxyl radical generating-activity became maximum during the rewarming period in the dark, so that the above possibility needs further investigation.

During the rewarming period, the NADPH-dependent superoxide generating-activity increased significantly in chilled 'Suyo' and 'Sharp I' leaves, which is attributable to post-chilling oxidative stress caused by a sudden temperature change (Tsang et al., 1991; Saruyama and Tanida, 1995). During this period, superoxide anions could affect membranes directly without conversion to hydroxyl radicals because in warm conditions superoxide anions may conjugate to perhydroxyl radicals that can attack polyunsaturated fatty acids directly (Bielski et al., 1983).

Production of superoxide anions is catalyzed by various univalent oxidases such as xanthine oxidase and aldehyde oxidase, but most likely by NADPH oxidase that uses NADPH as the electron source for the reduction of $\mathrm{O}_{2}$ to superoxide (Cakmak and Marschner, 1988; Ogawa et al., 1997). Our results indicate that the increase in the NADPH-dependent superoxide-generating activity in chilled cucumber leaves was mainly triggered by the chill-induced activation of NADPH oxidase.

The NADPH oxidase is located in various parts of plant cells, including cytoplasmic membranes (Ogawa et al., 1997), chloroplastic membranes (Feild, et al., 1998) and peroxisomal membranes (Lopez-Huertas et al., 1997). Cakmak and Marschner (1988) reported that activation of NADPH oxidase in microsomal membranes was responsible for the increased generation of superoxide anions in zinc deficient cotton roots. According to Ogawa et al. (1997), superoxide generation in vascular tissues of spinach hypocotyls, necessary for lignin biosynthesis, is catalyzed by $\mathrm{NAD}(\mathrm{P}) \mathrm{H}$ oxidase bound to cytoplasmic membranes. The site of NADPH oxidase that was activated in chilled 'Suyo' leaf cells is yet unknown.

Our present results indicate that the ability of leaves to prevent the activation of NADPH oxidase plays an important part in the high chilling tolerance of 'Jinchun No.3', but the regulatory mechanism of NADPH oxidase activity in chilled 'Jinchun No.3' leaves needs more study.

\section{Literature Cited}

Asada, K., M. Takahashi, K. Tanaka and N. Nakano. 1977. Formation of active oxygen and its fate in chloroplasts. p.45-63. In: O. Hayashi and K. Asada (eds.), Biological and medical aspects of active oxygen. Japan Sci. Soc. Press, Tokyo.

Bielski, B. H. J., R. L. Arudi and M. W. Sutherland. 1983. A study of the reactivity of $\mathrm{HO}_{2} / \mathrm{O}_{2}{ }^{-}$with unsaturated fatty acids. J. Biol. Chem. 258: 4759-4761.

Bradford, M. M. 1976. A rapid and sensitive method for the quantitation of microgram quantities protein utilizing 
the principle of protein-dye binding. Anal. Biochem. 72: $248-254$.

Brennan, T. and C. Frenkel. 1977. Involvement of hydrogen peroxide in the regulation of senescence in pear. Plant Physiol. 59: 411-416.

Cakmak, I. and H. Marschner. 1988. Enhanced superoxide radical production in roots of zinc-deficient plants. J. Exp. Bot. 39: 1449-1460.

Cakmak, I. and H. Marschner. 1988. Zinc-dependent changes in ESR signals, NADPH oxidase and plasma membrane permeability in cotton roots. Physiol. Plant. 73: $182-186$.

Croft, K. P. C., C. R. Voisey and A. J. Slusarenko. 1990. Mechanism of hypersensitive cell collapse: correlation of increased lipoxygenase activity with membrane damage in leaves of Phaseolus vulgaris (L.) innoculated with an avirulent race of Pseudomonas syringae pv. phaseolicola. Physiol. Molec. Plant Path. 36: 49-62.

Feild, T. S., L. Nedbal and D. R. Ort. 1998. Nonphotochemical reduction of the plastoquinone pool in sunflower leaves originates from chlororespiration. Plant Physiol. 116: 1209-1218.

Gupta, A. S., J. L. Heinen, A. S. Holaday, J. J. Burke and R. D. Allen. 1993. Increased resistance to oxidative stress in transgenic plants that overexpress chloroplastic $\mathrm{Cu} / \mathrm{Zn}$ superoxide dismutase. Proc. Natl. Acad. Sci. USA 90: $1629-1633$.

Hariyardi, P. and K. L. Parkin. 1993. Chilling-induced oxidative stress in cucumber (Cucumis sativus L., cv. Calypso) seedlings. J. Plant Physiol. 141: 733-738.

Heath, R. L. and L. Packer. 1968. Photoperoxidation in isolated chloroplast. I. Kinetics and stoichiometry of fatty acid peroxidation. Arch. Biochem. Biophys. 125: $189-198$.

Hosein, B. and G. Palmer. 1983. The kinetics and mechanism of oxidation of reduced spinach ferredoxin by molecular oxygen and its reduced products. Biochim. Biophys. Acta 723: 383-390.

Jakob, B. and U. Heber. 1996. Photoproduction and detoxification of hydroxyl radicals in chloroplasts and leaves and relation to photoinactivation of photosystem I and II . Plant Cell Physiol. 37: 629-635.

Kodama, H., T. Hamada, G. Horiguchi, M. Nishimura and K. Iba. 1994. Genetic enhancement of cold tolerance by expression of a gene for chloroplast $\omega-3$ fatty acid desaturase in transgenic tobacco. Plant Physiol. 105: $601-605$.

Lopez-Huertas, E., L. M. Sandalio, M. Gomez and L. A. Del Rio. 1997. Superoxide radical generation in peroxisomal membranes: Evidence for the participation of the $18-\mathrm{kDa}$ integral membrane polypeptide. Free Rad. Res.
26: $497-506$.

Lukatkin, A. S., E. Sh. Shakaeva and O. A. Zauralov. 1995. Lipid peroxidation in the leaves of heat-loving plants as dependent on the duration of cold stress. Rus. J. Plant Physiol. 42: 538-542.

Lynch, D. V. 1990. Chilling injury in plants: The relevance of membrane lipids. p.17-34. In: F. Katterman (ed.), Environmental injury to plants. Acad. Press, San Diego, Calif.

Lyons, J. M. 1973. Chilling injury of plants. Ann. Rev. Plant Physiol. 24: 445- 466.

Markhart, A. H. III ., M. M. Peet, N. Sinot and J. P. Kramer. 1980. Low temperature acclimation of root fatty acid composition, leaf potential, gas exchange and growth of soybean seedlings. Plant Cell Environ. 3: 435-441.

Murata, N., O. Ishizaki-Nishizawa, S. Higashi, H. Hayashi, Y. Tasaka and I. Nishida. 1992. Genetically engineered alteration in the chilling sensitivity of plants. Nature 356: $710-713$.

Ogawa, K., S. Kanematsu and K. Asada. 1997. Generation of superoxide anion and localization of $\mathrm{CuZn}$-superoxide dismutase in the vascular tissue of spinach hypocotyls: Their association with lignification. Plant Cell Physiol. 38: 1118-1126.

Pauls, K. P. and J. E. Thompson. 1984. Evidence for the accumulation of peroxidized lipids in membranes of senescing cotyledons. Plant Physiol. 75: 1152-1157.

Prasad, T. K., M. D. Anderson, B. A. Martin and C. R. Stewart. 1994. Evidence for chilling-induced oxidative stress in maize seedlings and a regulatory role for hydrogen peroxide. Plant Cell 6: 65-74.

Raison, J. K., E. A. Chapman and L. C. Wright. 1979. Membrane lipid transitions: Their correlation with the climatic distribution of plants. p.177-186. In: J. M. Lyons, D. Graham and J. K. Raison (eds.), Low temperature stress in crop plants. The role of the membrane. Acad. Press, London.

Salin, M. L. 1988. Toxic oxygen species and protective systems of the chloroplast. Physiol. Plant. 72: 681-689.

Saruyama, H. and M. Tanida. 1995. Effect of chilling on activated oxygen-scavenging enzymes in low temperature-sensitive and - tolerant cultivars of rice (Oryza sativa L.). Plant Sci. 109: 105-113.

Schwertner, H. A. and J. B. Biale. 1973. Lipid composition of plant mitochondria and of chloroplasts. J. Lipid Res. 14: $235-242$.

Tsang, E. W. T., C. Bowler, D. Herouart, W. Van Camp, R. Villarroel, C. Genetello, M. Van Montagu and D. Inze. 1991. Differential regulation of superoxide dismutases in plants exposed to environmental stress. Plant Cell 3: 783-792. 
低温耐性の異なるキュウリ品種の低温遭遇葉における酸素ラジカル生成活性

沈 文雲 $\cdot$ 名田和義・橘 昌司

三重大学生物資源学部 514-8507 津市上浜町 1515

摘 要

低温耐性の異なるキュウリ品種間で，低温遭遇中およびそ の後の葉の酸素ラジカル生成活性を比較した。 '津春三号”,

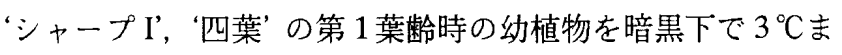

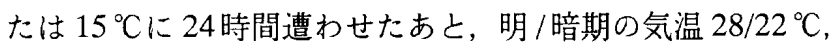
12 時間日長の人工気象室に移すと, 低温遭遇区の葉の周辺部 と中央部にネクロシス状の障害が現われ，それは時間ととも に拡大した. 3 品種の低温障害程度 (常温に戻して 24 時間後 の葉の障害面積率と, 引き続きガラス室で7日間栽培後の茎 葉の生長抑制程度) は “四葉”が最も大きく, 次いで ‘シャ一 プI’, ‘津春三号” の順であった。 また, 脂質過酸化の指標上 なるマロンジアルデヒド含量は低温遭遇中には増加しなかっ たが, 常温に戻すと次第に增加した. 常温に戻して 24 時間後 の 3 品種の葉のマロンジアルデヒド含量の増加程度は低温障 害程度とほぼ一致した。

‘四葉’の葉では, 低温遭遇中にNADPH低存性スーパーオ キシドと過酸化水素の生成活性が著しく高まった，常温に戻
すと過酸化水素生成活性が低下し，ヒドロキシルラジカル生 成活性か顕著に高まった。スーパーオキシド生成活性は低温 遭遇 24時間目に急速に低下したか，常温に戻した後に再び増 大した。 ‘シャープI'では, 常温に戻した後の前半に過酸化水 素とヒドロキシルラジカルの生成活性が増大し, 後半に NADPH 依存性スーパーオキシド生成活性が増大した。これ に対して, ‘津春三号”では, 低温遭遇葉の NADPH依存性ス一 パーオキシド生成活性は‘四葉”に比へて著しく小さかった。 また，NADPHオキシダーゼ活性は3品種ともNADPH依存 性スーパーオキシド生成活性とほほ比例して変動した。

以上の結果から, 酸素ラジカル生成活性の高まりによる膜 脂質過酸化の促進がキュウリ葉の低温障害の主要な要因であ ると考えられる. また，低温による酸素ラジカル生成活性の 高まりにはNADPHオキシダーゼの活性化が関与しており， その活性化程度がキュウリ品種の低温耐性に密接に関係して いると推察される. 